\title{
ÜZLETI HÁLÓZATOK VIZSGÁLATA ÉS FEJLESZTÉSE A VERSENYKÉPESSÉG NÖVELÉSE ÉRDEKÉBEN
}

\author{
Oláh Judit - Karmazin György - Erdei Edina - Popp József
}

\begin{abstract}
Absztrakt: Minden kereskedelemmel foglalkozó vállalat életében fontos az árueljuttatás hatékony, gyors megszervezése és végrehajtása. Napjainkban, ezen hálózatok és ellátási láncok versenye alakult ki, melynek egyik fö meghatározója a méretgazdaságosság (nagy földrajzi távolságok áthidalása költséghatékonyan) és a választékgazdaságosság (testreszabott szolgáltatások) színvonala. Kutatásunk a hálózatok jelenlegi feltérképezésével és kihasználtságával foglalkozik, mely során a logisztikai rendszerekben található szolgáltatók által üzemeltetett központok kapcsolatait mutatjuk be. A hálózatok bemutatását elhagyva, a rendszerek növekedési lehetöségeire teszünk javaslatot a „social network analysis" módszertan segítségével. Ennek során megállapítottuk, hogy a hálózatok fejlödését az egyes (küldeményazonosítási, termékkövetési, flotta menedzsment) rendszerek mellett a mobil applikációk is nagymértékben befolyásolják, melyek a termék időben történő érkezését teszik lehetövé.
\end{abstract}

\begin{abstract}
In the life of every trading company, it is important to organize and implement the delivery of goods efficiently and quickly. Nowadays, competition have emerged between of networks and supply chains, whose most important factors are the economies of scope and scale (that are related to the cost-effective bridging of large geographical distances and to customized services). Our research deals with the discovery and utilization of the networks, showing the connections of the centers operated by the service providers in the logistic systems. Leaving the presentation of the networks, using the "social network analysis" methodology we propose ways so that the systems can develop. We have determined that the development of networks is also largely influenced by mobile applications, besides certain (mail identification, product tracking, fleet management) systems, which allow the product to arrive on time.
\end{abstract}

Kulcsszavak: ellátási lánc, kapcsolati hálózat, social network analysis

Keywords: supply chain, connection network, social network analysis

\section{Bevezetés}

A piac folyamatosan változik, ezért ahhoz, hogy a szolgáltató és az ipari vállalatok fenntartsák vagy javítsák meglévő piaci helyzetüket, létfontosságú az alkalmazkodás képessége. Egy vállalat piacon való elhelyezkedését nagymértékben meghatározza versenyképessége, vevőközpontúsága, rugalmassága és ellátási hálókban lévő szerepe (Takács-György-Toyserkani, 2014).

Kutatásunk során az elmúlt években egyre elterjedtebbé vált hálózatkutatás eszköztárának vizsgálatával foglalkozunk. Ezalatt fontosnak tartjuk, hogy az ellátási háló fogalmát pontosan definiáljuk: mindazon folyamatok és készletek célorientált hálózata, amelyek termékeket vagy szolgáltatásokat juttatnak el a fogyasztóhoz (Hopp, 2008).

Kutatásunk a Magyarországon bejegyzett és müködő logisztikai szolgáltató vállalatok körében történt. A megkérdezett hazai logisztikai vállalkozásokról feltételezhetö, hogy - méretüket és szolgáltatásaik széles spektrumát tekintve napjainkra már jelentős közvetítöi szerepet látnak el. Éppen ezért, ezeket az úgynevezett csomópontokat a social network analysis (SNA) segítségével elemezzük. 
Az SNA egyre növekvő népszerüségét az adatrendszerek és azok feldolgozási módszereinek tulajdoníthatjuk. A vállalati gyakorlatok kifejlesztése a hálózatkutatás alapelveire támaszkodva mára már hatékonyabbnak bizonyul, mintha más szervezetek már alkalmazott megoldásait vennék át (Hopp, 2009). Ezeknek is köszönhetően a makroszintü szervezetelemzés területén a hálózatkutatás alapvető fontosságúvá vált (Galaskokiewicz, 2011).

A hálózatok felderítésekor megállapítást nyert az, hogy azokat a csomópontokat, amelyek több kapcsolattal rendelkeznek, szívesebben választjuk ki. Ennek következménye, hogy az ,időben való belépés” jelentősen hozzájárul egy középpont növekedéséhez (Barabási, 2013:99).

Elemzésünk során az informatikai eszközök fejlesztése mellett a bizalom, az alkalmasság és a robusztusság vizsgálatára, valamint az utak fejlesztésére is kitérünk, melyek elösegítik az ellátási hálózatok vertikális növekedését, ezáltal a gazdasági folyamatok fellendítését.

\section{1. Üzleti hálózatok}

A globális gazdaság szerkezetét üzleti hálózatok alkotják, amelyek a folyamatosan fejlődö, változó gazdasági környezet hatására jöttek létre. A hálózatosodás során a vállalatok jelentős versenyelönyre tehettek szert, hiszen azok kiépítése hosszabb távú fennmaradást eredményez. Az üzleti hálózat egy úgynevezett struktúra, amelyben csomópontok szálakon keresztül kapcsolódnak egymáshoz. Ezek a csomópontok az üzleti egységek (mint például logisztikai vagy pénzügyi szolgáltatók, vevők, termelö vállalatok), az összekötő szálak pedig a kapcsolatok. (Gelei, 2008: 4). A kis- és középvállalati kör számára kulcsfontosságú, hogy bekapcsolódjanak az áramlásba, csak így válhatnak valós piaci szereplőkké. Az információhoz való hozzáféréshez, az innovációs folyamatokban történő elöre lépéshez is egyre fontosabb a kapcsolatok sokasága, megnö az interperszonális kommunikációs csatornák (pl.: szakemberek közötti véleménycsere) jelentősége (Csizmadia, 2009; Takács-György-Takács, 2011).

Kis (2014) szerint a vállalkozói gazdaság meghatározó kulturális tényezöje a társadalmi töke magas szintje és a változásra (innovációra) való nagyfokú fogékonyság és képesség. A vállalkozói gazdaság vállalkozásai jellemzően kisméretüek, KKV-k, amelyek hálózataik révén müködésük számos területén alakíthatnak ki kölcsönösen hasznos együttmüködéseket, így biztosítva maguknak a rugalmas alkalmazkodásból és a mérethatékonyságból származó elönyök kiaknázását, ami számottevően hozzájárulhat versenyképességük fokozásához.

A hazai vállalkozások méretbeli eloszlását vizsgálva és a nemzetközi modellekkel összevetve csak abban bizakodhatunk, hogy a magyar kis-és középvállalatok a globalizálódó üzleti hálózatok részeként boldogulni fognak (Gelei, 2010). Ezt alátámasztja a következő könyv idézet is: „A KSH (2013) vállalati hozzáadott értékre közölt adatai szerint, a nemzetközi tapasztalatokhoz hasonlóan Magyarországon is sokkal termelékenyebbek a külföldi tulajdonossal rendelkezö vállalatok. A magyar tulajdoni hátterủ cégek 2011-ben egy főre 4.461 ezer forint, a 
külföldiek pedig 11.334 ezer forint hozzáadott értéket állítottak elö. A különbség két és félszeres." (Reszegi-Juhász, 2014:14).

Fontos, hogy a hazai tulajdonban lévő vállalatok üzleti hálóikat megfelelöen alakítsák ki és megtalálják azokat a stratégiákat, amelyeknek köszönhetően csökkenhet - a külföldi vállalatokhoz hasonlítva - a termelékenységbeli különbség.

\subsection{Logisztikai hálózatok}

A növekvő globalizáció, versenyképesség és vevői igények következtében az utóbbi években nagymértékben fejlödtek azok a logisztikai módszerek és megoldások, amelyek az anyagáramlás rendszerszemléletü kezelésén alapulnak. Ez a fejlődés megfigyelhető volt a termelő és a fogyasztó helyeken, a vállalatok közötti közvetlen szállítási kapcsolatokban, majd az összetett ellátási láncokban és hálózatokban. Az elmúlt közel két évtizedben a fejlett ipari országokban a termékek életciklusa rohamosan csökkent, melynek folytán a beszerzés, gyártás és értékesítés ideje meghatározóbb lett, a részfolyamatok lerövidültek, a készletek mennyisége csökkent.

A versenyelőny megszerzése nem az erőforrás típusú elönyökben rejlik, hanem a folyamat típusú előnyökben. Ennek köszönhetően a logisztikát szélesebb környezetben is vizsgálni szükséges ott, ahol az komplex makrogazdasági szerepet játszik és segíti a versenyképes ipari háttér kialakulását. A nemzetközi és hazai útvonalakon történő áruszállítás a csomópontokhoz (HUB), azoktól, vagy azokon keresztuil, lehetővé teszi az áruk hatékony áramlását. Ez zökkenömentes és intelligens összekötő folyosók fejlesztésének szükségességéhez vezet az ipari vagy logisztikai klaszterek között, amely valós idejü kapcsolatot, stabil és biztonságos infrastruktúrát, az információk megosztását, az adminisztratív terhek csökkentését, fokozott vezérlést és rugalmas szolgáltatást eredményez. A jelenlegi magyarországi vasúti hálózatot az 1. ábra mutatja be. Látható, hogy hazánk vasúti útvonalainak hálószerü kiépítése sikeresen megtörtént, viszont a járművek és pályák további minőségi fejlesztése is elengedhetetlen a hatékonyság és gyorsaság kiaknázásához.

A fenti fejlesztések szorgalmazását a logisztikai szolgáltatók annak érdekében teszik, hogy megbirkózzanak a végfelhasználók növekvő igényeivel és a fogyasztók számára megbízható, gyors, pontos és kedvezőbb szállítást biztosítsanak. Ennek eléréséhez együttmüködésre és közös eröfeszítésekre van szükség, hogy a rendelkezésre álló tudás, az információs és kommunikációs technológia és az operatív végrehajtás a lehetö leghatékonyabb legyen.

A gazdaságra általánosan is hálózatként kell tekinteni, amely különböző közlekedési útvonalak informatikai és infrastrukturális összekötésével valósítja meg az ellátási láncok menedzsmentjét. Ezeknek a rendszereknek az információáramlását jelentősen támogatja az internet, a hatékonyságát pedig nagyban növeli a technológiai és az innovációs fejlesztések legjobb alkalmazása. 


\section{1. ábra: Magyarország vasúthálózati térképe 2016-ban}

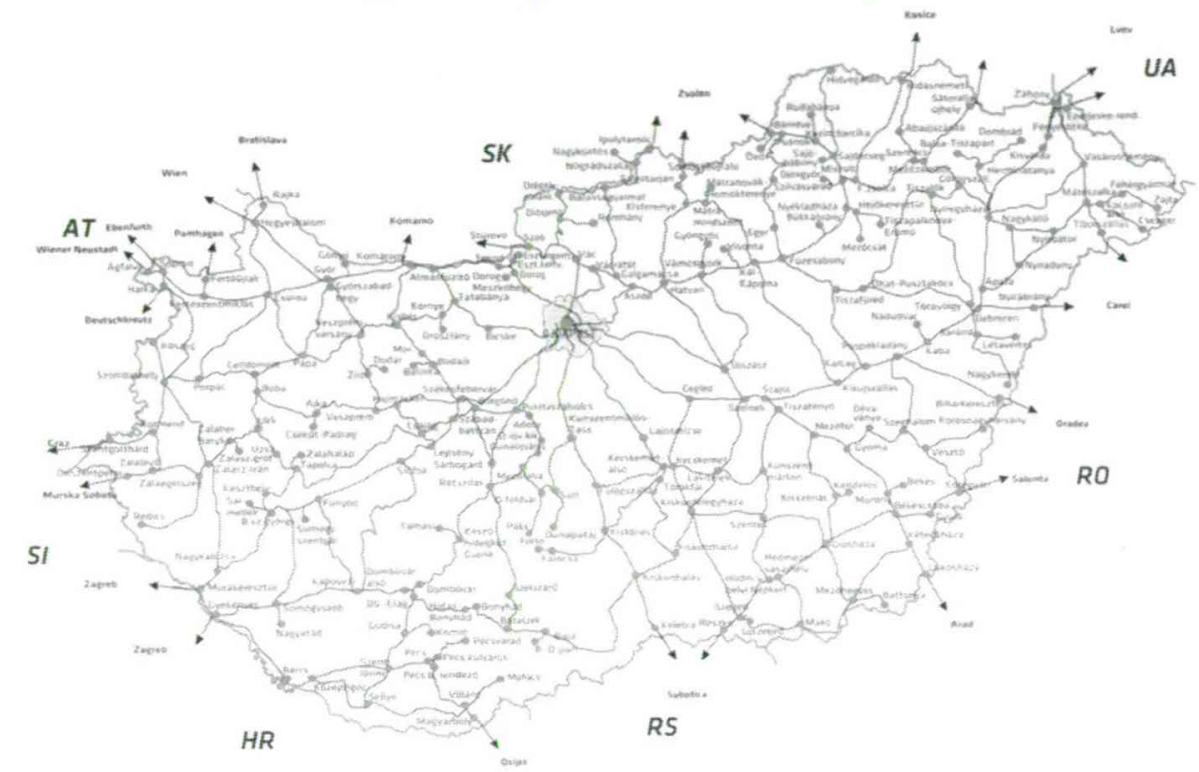

Forrás: Közlekedéstudományi Intézet (2016)

\section{Anyag és módszer}

Kutatásunk során Magyarország üzleti és logisztikai hálózatát vizsgáltuk meg az SNA módszertan segítségével, amely az emberek, szervezetek, információk és folyamatok feltérképezésére és mérésére szolgál. Az elmúlt években az SNA egyre elfogadottabb módszertanná vált a logisztika területén is, mivel interdiszciplináris összekötő kapocsként képes az ellátási hálók változását elemezni és müködésük javításával hatékonyabbá tenni azokat.

A korábban elterjedt nézet szerint az ellátási hálókban a sebességet a termék értékláncon történő áthaladási ideje határozza meg. Ezzel szemben az SNA a szereplők közötti kapcsolatokra fókuszál: a gyenge kapcsolatokra, amelyek gyakran ismeretségi kapcsolatokként állnak fenn; az erös kapcsolatokra, amelyek jellemzője a szoros kötődések (például családi, rokoni szál) megléte.

A módszer metodológiájában számos mérési eljárás létezik. Ezek közül a hálózat nagyságát a szereplők száma alapján határozza meg, sủrüségét a szereplők közötti összes meglévö kapcsolat hányadát alkalmazva írja el. Fontos továbbá a központiság kérdése is, mely a hálózat szereplöinek az elhelyezkedését globális és helyi szinten is képes megmutatni, valamint a fok, mely magában foglalja az adott csomópontokat. Ez segíti megkülönböztetni a „népszerü” és „,népszerūtlen” node-okat. A közöttiség vizsgálja, hogy az adott szereplő hálózati elhelyezkedése mennyire kritikus az információáramlás és a hálózati együttmüködés szempontjából. Az „eigenvector” megmutatja az adott csomópontok fontosságát a hálózatban.

$\mathrm{Az}$ üzleti kapcsolatok kialakítása során a vállalatok vezetőinek többnyire megvan az a lehetősége, hogy több lehetséges partner (jelentkező) közül válasszák 
ki a számukra legmegfelelőbb vállalkozást az együttmüködés kialakítása céljából. Itt arra keressük a választ, hogy a kiválasztásnak mekkora hatása van a későbbi együttmüködésre (bizalom szintjére), és annak mekkora lesz a szerepe az együttmüködő társaságok eredményességében.

\section{Az eredmények értékelése}

A mai fogyasztók vásárlási szokásai nagymértékben eltérnek az előző időszakban tapasztaltaktól (Sg.hu, 2014). Az internet elterjedésének és a fogyasztói magatartás változásának köszönhetően egyre nagyobb hangsúlyt kapnak a vevők idővel kapcsolatos elvárásai. A felgyorsult élet gyorsabb ellátási láncokat, és ezáltal olyan logisztikai megoldásokat követel, amelyek támogatják a termék vagy szolgáltatás időben történő érkezését.

Az SNA segítségével feltérképeztük, hogy az első és a legfontosabb az ellátási lánc tagvállalatainak belső folyamatait támogató vállalatirányítási rendszerek bevezetése és alkalmazása, amelyek az együttmüködések során a vállalatok közötti információátadást támogató interfészekkel egészülnek ki. Ezek a kapcsolatok az információk folyamatos, gyors és biztonságos áramlását segítik elö, többnyire „papírmentes” információáramlást biztosítva az üzleti partnerek között.

Az ellátási láncok fontos tagját képezik továbbá azok a rendszerek, melyek a nyomon követhetőséget és visszakereshetőséget támogatják (küldeményazonosítási rendszer, termékkövetési és azonosítási rendszer). A 2000-es évek közepén infokommunikációs technológiaként megjelentek a Flotta Menedzsment Rendszerek (FMR), mely mára már alapkövetelményként épültek be a vevői elvárásokba (Karmazin, 2011). A forradalmian új technológiák között megemlíthetjük a mobil applikációk megjelenését is (például Uber) a fogyasztók kiszolgálásában. Az alkalmazás elsőként a személyszállításban jelent meg a világ több nagyvárosában, de a fejlesztők szerint a jövőben bemutatkozhatnak az ételfutár és a csomagküldö applikációk is (VG, 2015b).

A hálózati analitikát vizsgálva az e-kereskedelem népszerüségét is felfedeztük, és megállapítottuk, hogy előrejelzései jelentős hatással lesznek a logisztikai rendszerekben megjelenő árualapok növekedésére, azok méretére és diverzifikáltságára. A globális áruforgalom növekedése, valamint az e-kereskedelmi forgalom elörejelzései - csak Kínában évi 20\%-os növekedést prognosztizál 2019ig a Forrester (2015) - folyamatosan ösztönzik, a világot átszövő logisztikai hálózatokat a dinamikus fejlödésre. A földrajzi kitekintést Európára szükítve, itt is az e-kereskedelem növekvö térhódításával szembesülhetünk. Németországban a kereskedők azt tapasztalják, hogy a fogyasztók előszeretettel vásárolnak az interneten keresztül személyes eladást feltételező termékeket is (például cipőket és szemüvegkereteket) (BrandTrend, 2014). Magyarországon az e-kereskedelem részaránya még csak 3\% (Balatoni, 2015), ellenben ez a jövőben a nyugat-európai szint $(6 \%)$ közelébe fog növekedni.

A fenti tények alapján látható, hogy az e-kereskedelem felfutása és térnyerése miatt elindult verseny jelentősen át fogja rajzolni a logisztikai rendszerek, megoldások és a piaci szereplők ,térképét”, továbbá megállapíthatjuk, hogy a 
vállalatok közötti együttmüködések és a logisztikai szolgáltatók integrációja az ellátási láncban, elképzelhetetlen magas színvonalú informatikai támogatás nélkül.

Hazánk globális, logisztikai szempontból vett versenyképessége nagyban függ a közlekedési infrastruktúra fejlettségétől, állapotától. A World Economics Fórum minden évben - 2012-ben 111 mutató alapján a világ 144 országát - rangsorolja az országokat versenyképességük szerint. A versenyképességi rangsor összeállítása során mért mutatók között megtalálhatjuk az infrastruktúra hiányosságait, amelyben Magyarország 4,4 ponttal az 50. helyet foglalja el. Ez azt jelenti, hogy a fejlödés irányába haladunk, viszont Magyarország jelenkori közúti, vízi, vasúti hálózatát a gyorsabb termékkiszolgálás érdekében fejleszteni szükséges.

Magyarország közúti közlekedési infrastruktúrájának elemeit a 2. ábra mutatja, melyen észrevehetjük, hogy az áruszállítás teljesítménye Magyarországon 2012-es évben lecsökkent, ennek ellenére a nemzetközi szállítás ereje megnőtt.

\section{2. ábra: Közúti áruszállítási teljesítmény Magyarországon}

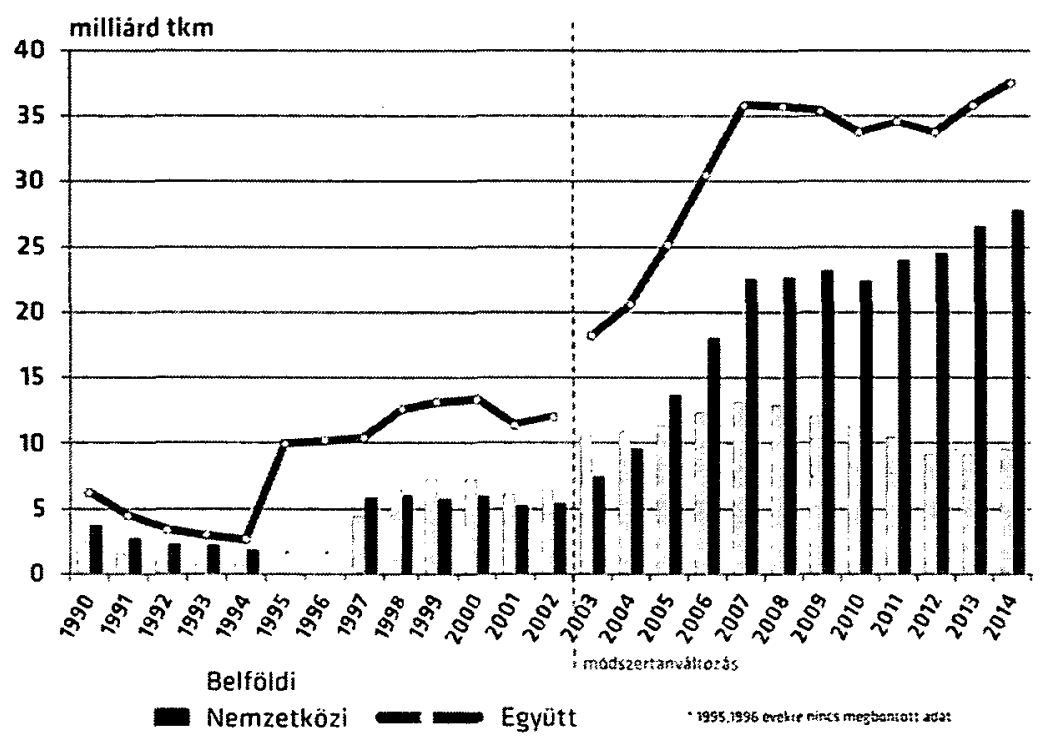

Forrás: Közlekedéstudományi Intézet (2015)

A social network analysis segítségével megállapítható, hogy Magyarországon elengedhetetlen az autópályák fejlesztése. A meglévő autópályák mellett számos útvonal kialakítása is tervben van, mely elősegítené a termékek gyorsabb kiszállítását. A közúti árutovábbítás esetén kiemelkedik a régióközi kapcsolatok szintje, a városközi és faluközi kapcsolatok rovására. A jövöben törekedni kell a centrikus közlekedési hálózat további fejlesztésére, illetve ezen útvonalak alternatívaként jelentkező összekötésének kialakítására (M8, M9), amelyek természetesen a logisztikai fejlesztések szempontjából is meghatározóvá fognak válni. Ezen terv kialakítása a 3. ábrán is jól látható. 


\section{3. ábra: Autópályafejlesztés Magyarországon}

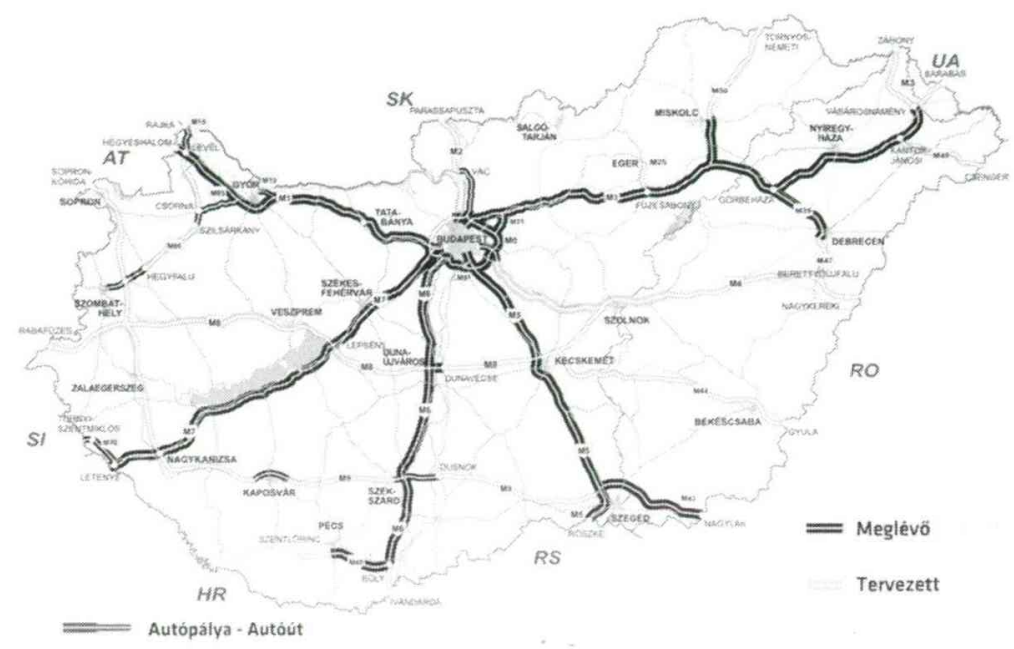

Forrás: Közlekedéstudományi Intézet (2015)

A logisztikai szolgáltatók egyik legjobb üzleti mérőszámaként szolgálnak a nemzetközi hajós társaságok által közölt, következő negyedévekre vonatkozó hajófoglaltsági mutatók adatai, illetve az SNA mutatók alapján képzett és általuk alkalmazott jövőbeli időszakra vonatkozó vállalási árak (fuvardíjak) adatai. A Közlekedéstudományi Intézet megállapítása szerint Magyarországon egyre nagyobb hangsúly kerül a belvízi hajózásra. Olyannyira, hogy 2050-re ezen közlekedési alágazat teljesítményét a jelenlegi négyszeresére várják (4. ábra). Ez a fellendülés természetesen nem azt jelenti, hogy a közúti és vasúti fuvarozás kihasználtsága csökkenni fog.

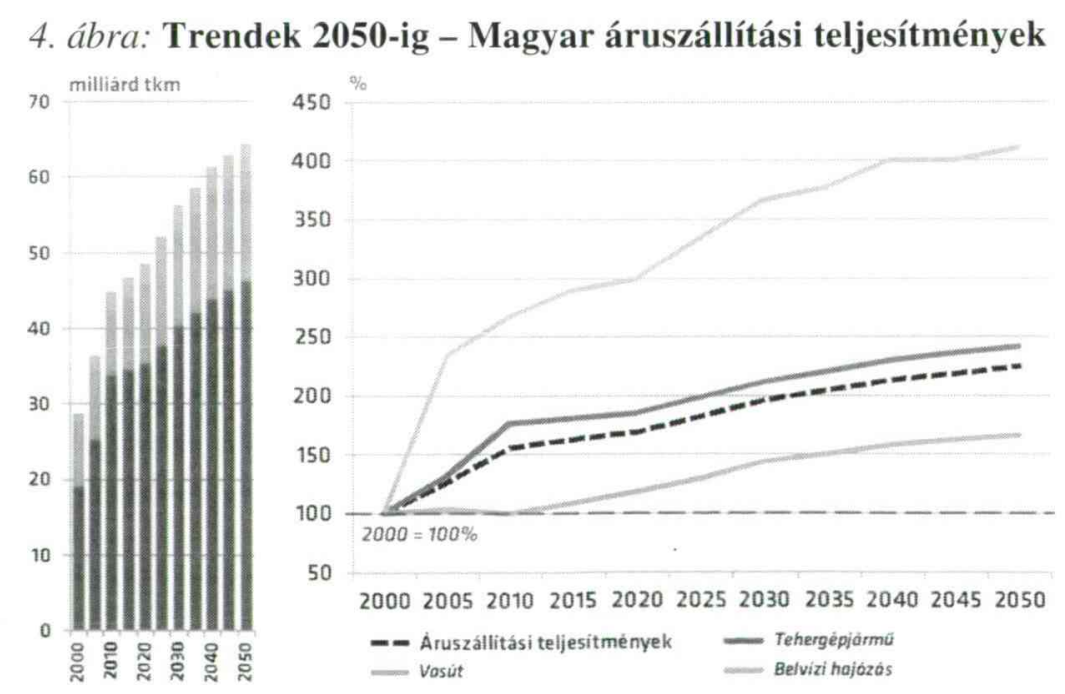

Forrás: Közlekedéstudományi Intézet (2014) 
A 4. ábra szerint az áruszállítás teljesítménye megduplázódik és mind a vasúti, mind pedig a közúti jármúvek használata mellett a belvízi hajózás eszköz-használata is növekedni fog. Jelenleg a kontinensek közötti áruáramlások jelentős része konténerekben történik. A Simon által végzett felmérés megállapította, hogy a nemzetközi konténeres szállítás trendje felfelé mutató „volumene évente 10,8\%-kal nött 2000 és 2005 között, és közép-, valamint hosszútávon további növekedés várható" (Simon, 2010: 131). Ez azt jelenti, hogy kiegyensúlyozott gazdasági környezetben a világszerte szállított konténerek száma kb. 7 évente megduplázódik. Ez a kapacitásnövekedési trend, jelentős hatással van a logisztikai piac szereplöire és kihívásként jelenik meg a logisztikai rendszerek müködtetésében.

A közlekedési rendszerek fenti elemzéséröl a logisztikai szolgáltatók által müködtetett HUB-ok körében végzett vizsgálatok eredményeire átlépve kijelenthetjük, hogy az üzleti tevékenységük legjobb kialakítása során itt is igazak lehetnek, a hálózati pont fejlődésére vonatkozó hálózatelméleti következtetések és megállapítások. Ennek megfelelően az 1. táblázat jól összefoglalja a hálózatelmélet eredményeit és áltạános következtetéseit, továbbá javaslatot is tesz az üzleti stratégiákat támogató tevékenységekre, mint például az alkalmasságra, népszerüségre, robosztusságra stb. (Karmazin, 2015).

\section{1. táblázat: A hálózati pontok fejlódése és a logisztikai szolgáltatók stratégiáit megvalósító támogatói tevékenységek összefüggései}

\begin{tabular}{|l|l|}
\hline Hálózati pont fejlödése & \multicolumn{1}{|c|}{$\begin{array}{c}\text { Logisztikai szolgáltatók stratégiáit megvalósító támogatói } \\
\text { tevékenységek }\end{array}$} \\
\hline népszerüség & $\begin{array}{l}\text { hatékony PR és marketing tevékenység, bizalomszint emelése az } \\
\text { üzleti kapcsolatokban, új ágazatok felé nyitás, új kapcsolatok } \\
\text { kialakítása }\end{array}$ \\
\hline középpont (nagyság) & $\begin{array}{l}\text { növekedési stratégia elfogadtatása a vállalati szervezeten belül, } \\
\text { együttmüködések kialakítása akár konkurens vállalatokkal is }\end{array}$ \\
\hline idöben való belépés & $\begin{array}{l}\text { rugalmasság, okozói/proaktív magatartás, új piacokra lépés, új } \\
\text { szolgáltatások és technológiák bevezetése, alkalmazása, trendek } \\
\text { felismerése és innovatív technológiák alkalmazása }\end{array}$ \\
\hline $\begin{array}{l}\text { gyenge kapcsolatok } \\
\text { ereje }\end{array}$ & $\begin{array}{l}\text { társaságokhoz, közösségekhez való csatlakozás, együttmüködési } \\
\text { szerzödések kialakítása, idegen rendezvényeken való részvétel, } \\
\text { gazdasági események szervezése és támogatása, non-profit } \\
\text { tevékenységek és támogatások }\end{array}$ \\
\hline alkalmasság & $\begin{array}{l}\text { változásra való képesség fejlesztése, ágazat-specifikus informatikai } \\
\text { fejlesztések, folyamatos képzés, nyitottság az újdonságok irányába, } \\
\text { jármüvek és raktárkapacitások átalakítása }\end{array}$ \\
\hline $\begin{array}{l}\text { robusztusság } \\
\text { (hibafeloldás) }\end{array}$ & $\begin{array}{l}\text { minöségmenedzsment magas szintü alkalmazása, javítóó } \\
\text { mechanizmus beépítése az üzleti folyamatokba, döntések } \\
\text { atacsonyabb szintre engedélyezése, redundanciák }\end{array}$ \\
\hline
\end{tabular}

Forrás: Duma-Karmazin (2015:4)

Watts és Strogatz alapcikkükben a „kis világ” jelenségét és jellegzetességeit tárták fel. Dinamikus rendszermodellezéssel hívták fel a figyelmet arra, hogy az 
ilyen típusú hálózatokban a csoportképződésnek és a magas fokú koncentrációnak sajátos következményei vannak, pl.: fokozottabb terjedési sebesség, vagy teljesítmény (Watts-Strogatz,1998:440). De mi lesz a későn jövőkkel, akik koruknál vagy ötletüknél fogva később lépnek be egy már müködő üzleti hálózatba? Megvizsgálva azt a folyamatot, amely elválasztja a győzteseket a vesztesektől, láthatjuk, hogy a komplex rendszerekben megjelenő verseny esélyt ad a jobban alkalmazkodó vállalkozásoknak arra, hogy „fittségüknek” köszönhetően elönyre tegyenek szert a versenytársaikkal szemben. Ezt nevezhetjük az alkalmasság szabályának, amely alapjában „nem szünteti meg a növekedési és a népszerüségi kapcsolódást" (Barabási, 2013:109) szabályzó mechanizmusokat.

$\mathrm{Az}$ 1. táblázat utolsó pontjának tekintetében a robusztusságnál konkrétabb fogalom a zavarérzékenység és a hibafeloldó képesség. A szállító hálózatokra jellemző, lavinaszerü meghibásodásra elvégzett szimulációk alapján bizonyított, hogy egy hálózatban a kaszkádszerü összeomlások hatása mérsékelhető az egyes diszkrét elérési helyek leállás-, azaz zavar-érzékenységének csökkentésével (Duma, 2005). Ennek egyértelmü tanulsága, hogy a termelési pontok, mint diszkrét források, legalább annyira hozzájárulnak egy rendszer fenntartható müködéséhez, mint maguknak a szállítási útvonalaknak a minösége, stabilitása és érzékenysége. A leállás-érzékenység korábban nem szerepelt az ellátási lánc jóságának jellemzésében. Nem (csak) azért állhat egy termelö hely és végső soron egy egész ellátási lánc, mert nem szállítanak neki vagy benne, hanem azért is, mert nem képes arra, hogy az elszállítás mértékének esetleges csökkenésével saját termelését más üzemméretre állítsa át. Mivel ilyenkor éppen a hálózatosodó logisztikai kapcsolatoknak köszönhetően más szállítási útvonalakra, közlekedési alágazatokra, stb. terelik át a forgalmat, egyértelmüen a lavinaszerü meghibásodást látjuk, amelynek oka nem csak a szállítási rendszerek karakterisztikájában, hanem a források és a nyelők karakterisztikájában, zavarérzékenységében is keresendő (Duma, 2005).

Az SNA szerint az ember által müködtetett rendszerekben gyakran elöfordul, hogy a legkisebb meghibásodások hatására is működésképtelenné válik. Ebből kifolyólag a robusztusság vizsgálata a jövőben fontos tanulságokkal járhat a müködőképességre vonatkozóan, hiszen minden rendszernek a müködőképességét „egy bonyolult, szorosan összefüggő hálózat garantálja” (Barabási, 2013:125). A fenti szabályok figyelembe vételével ma már Barabási és csoportja arra is tud vállalkozni, hogy egy adott dinamikus, skálafüggetlen hálózatról megmondja, hogy „a gazdag egyre gazdagabb lesz" vagy a „győztes mindent visz” sémát követi. Ez az ún. Máté-effektus (Mérö, 2012).

A hazai logisztikai szolgáltató vállalatok körében végzett reprezentatív, primer és empirikus kutatások eredményeit vizsgálva bátran leírhatjuk azt, hogy az általános bizalomszint nemcsak a társadalomban élö egyének viszonyaira és együttmüködésére, illetve általánosságban a vállalatok gazdálkodására van pozitív hatással, hanem a logisztikai szolgáltató vállalatok adózás előtti eredményére is. Söt a vevő által érzékelt teljesítmény meghatározó tényezői közül a környezeti bizalom a rugalmasságra is meghatározó jelentőséggel bír. Továbbá égyes kutatók 
megállapításaira való hivatkozással kijelenthetjük azt is, hogy a hazai logisztikai vállalatok körében a vállalaton belüli - beosztottakkal kapcsolatos - nagyobb bizalom javítja a vállalat adózás előtti eredményének pozitív irányú változását.

A szervezetek közötti kapcsolatok elemzése szempontjából különösen fontos a bizalom és az opportunizmus problematikájának vizsgálata (Galaskiewicz, 2011). A bizalom kérdéskörének - az ellátási hálókkal kapcsolatos - elemzése már korán megkezdődött. Az egyének és/vagy a szervezetek közötti kapcsolatok a bizalomra épülnek, amivel a kockázatokat is csökkentik. A hálózati struktúrák segítik és gyorsítják a bizalom kiépítését, illetve segítik az információáramlást a szereplők között. Azt azonban nem szabad elfelejteni, hogy az ellátási hálók az üzleti környezetben nem minden esetben profitálnak a túl szoros kapcsolatokból. A legsikeresebb hálózati stratégia az, ha körültekintően egyszerre jelennek meg a gyenge és az erős kapcsolatok az érintett ellátási hálóban. A szoros kapcsolatok biztosítják a szereplök/partnerek lojalitását, míg a gyenge kapcsolatok hozzáférést biztosítanak az új ötletekhez, innovációkhoz és alternatívákhoz, nem egy esetben kedvezőbb feltételekkel, mintha csak erös kapcsolatok jelennének meg a hálózatban.

Tanulságként megállapíthatjuk, hogy a megrendelö-logisztikai szolgáltató kapcsolatában a partnerségre törekvés és együttgondolkodás több kommunikációval és szorosabb együttmüködéssel jár, ami többnyire win-win helyzeteket eredményez. A kommunikáció mennyisége és minösége, a jól teljesítés, az elvárásoknak való megfelelés, a rendelkezésre állás, a fizetési feltételek teljesítése mind-mind növelik a partnerekben kialakuló bizalom nagyságát.

\section{Záró gondolatok}

Elmondhatjuk, hogy a fenti megállapítások és javaslatok jelentős szerepet játszhatnak a magyar logisztikai szolgáltatók stratégiájában. A feldolgozott hálózatelméleti megközelítés és következtetés új szemléletet hozhat a magyar logisztikai központokat működtető hazai szolgáltató vállalatok döntéshozói számára. Megállapítást nyert az, ha a hálózat egyik részében változás következik be, az kihatással van az ellátási háló egész struktúrájára, ezért a vállalatok számára különösen kritikus, hogy folyamatosan ellenörzésük és irányításuk alatt tudják tartani a folyamatokat. Ez azonban a globalizációs hatások miatt nem mindig lehetséges, hiszen a hálózat különböző szereplöinek nagy valószínüséggel nemzetközi környezetben, eltérö müködési környezettel (politikai, jogi, gazdasági stb.) és feltételekkel kell szembenézni.

Az SNA segítségével nemcsak iparági szinten figyelhető meg a hálózati struktúra, hanem az egyes szereplők kapcsolati hálója is feltérképezhető, amelynek elemzésével lehetőség nyílik az ellátási háló javítása mellett az ügyfélszolgálati tevékenységek javítására, mely biztosíthatja a meglévő szolgáltatások és tarifarendszerek értékelését, illetve segíthet új szolgáltatások és/vagy árazás kialakításában. Az SNA alkalmazása az ellátási hálók esetében mindazon területeken célszerü, ahol az ellátási hálók során a termelö/szolgáltató és a fogyasztók közötti kapcsolatokban a gyenge és az erös kapcsolatok kiemelt szerephez jutnak. Véleményünk szerint a hálózatos iparágak, sajátos logikájuknál fogva, ideális 
kiindulópontot jelentenek. A jövőbeni kutatásainkban ezért figyelembe kívánjuk még venni a tulajdonjogok megváltozott szerepét Máté (2014) alapján ebben az ágazati aspektusban is.

Összefoglalásként azt is megállapíthatjuk, hogy az informatikai eszközök nagyban befolyásolják a gazdasági folyamatok fellendítését és a kapcsolati hálók gyorsabb kialakítását. Emellett az időben való belépés, alkalmasság, bizalmasság, népszerüség és robusztusság is hozzájárul az ellátási láncok biztonságos kiépítéséhez, melyek a vállalatok hosszabb távú fennmaradását teszik lehetővé.

\section{Irodalomjegyzék}

Balatoni J. (2015): A bevásárlóközpontok jelene és jövője. A kereskedelem perspektívái 2015 konferencia, Budapesti Gazdasági Föiskola, Budapest.

Barabási A. L. (2013): Behálózva. A hálózatok új tudománya. Helikon Kiadó, Budapest.

Bihari C., Fülöp B., Fülöp, L. (2013): 3 PL szolgáltatók integrációja az ellátási láncban - fókuszban az IT. Budapesti Corvinus Egyetem, Budapest.

BrandTrend (2014): Még mindig olcsóbb a nemzetközi online vásárlás. http://brandtrend.hu/aktualis/2014/03/05/meg-mindig-olcsobb-a-nemzetkozi-online-vasarlas. (2016.12.15.)

Csizmadia Z. (2009): Együttmüködés és újitóképesség: Kapcsolati hálózatok és innovációs rendszerek regionális sajátosságai, Napvilág Kiadó, Budapest.

Duma L. (2005): A logisztikai üzleti modellek és értékelés módszerek a hálózati gazdaságban, PhD disszertáció, BME, Budapest.

Galaskiewicz, J. (2011): Studying Supply Chains from a Social Network Perspective. In: Journal of Supply Chain Management, January 2011, 47 (1): 4-8.

Gelei A. (2008): Hálózat - a globális gazdaság kvázi szervezete. 95. sz. Mühelytanulmány, Budapesti Corvinus Egyetem Vállalatgazdaságtan Intézet, 2008. június

Gelei A. (2010): Az ellátási lánc menedzsmentje. In: Czakó E., Reszegi L. (szerk.): Nemzetközi vállalatgazdaságtan. Alinea Kiadó, Budapest, 413-441.

Hopp, W. J. (2008): Supply Chain Science. McGraw Hill/Irwin, New York

Hopp, W. J. (2009): Network Principles: Insights into Superior Execution and Innovation; elöadás a Figyelö TOP 200 konferencián, Herceghalom, 2009. október 15.

Karmazin Gy. (2011): The introduction of fleet management system (FMS) in BI-KA Logistics Ltd., In: Madaras Lászlóné et. al (szerk.): Economica, IV. új évfolyam, különszám, Szolnoki Fỏiskola, $13-18$.

Karmazin Gy. (2015): Logisztikai szolgáltató központok fejlesztése hálózati kutatások eredményeinek felhasználásával. Economica, 8 (1): 35-39.

Kis K. (2014): Vidékgazdaság, kultúra, Iokalizáció: eltérő válaszok és fejlödési differenciák. Jelenkori Társadalmi és Gazdasági Folyamatok, 9 (1-2): 9-28.

Máté D. (2014): Can intellectual property rights impact directly on productivity: a case study in manufacturing industries, Vezetéstudomány, 45 (11): 25-32.

Mérö L. (2012): Felkészülés az elképzelhetetlenre. IBM - „Váltsunk stratégiát!”, Budapest.

Reszegi L., Juhász, P. (2014): A vállalati teljesitmény nyomában. Alinea Kiadó, Budapest.

Sg.hu (2014): Az online vásárlók száma elérte a 3,4 millió fö́t Magyarországon. http://sg.hu/cikkek/106206/az-online-vasarlok-szama-elerte-a-34-millio-fot-magyarorszagon. (2017.02.14.)

Simon H. (2010): Rejtett bajnokok a 21. században. Leadership Kft., Budapest.

Simon J., Tóth Z. (2010): A bizalom alakulása a gazdasági és pénzügyi világválság alatt. Dél-Kelet Európa - South Eastem Europe, International Relations Quarterly, 1 (3): 1-8.

Takács-György K., Toyserkani, A. M. P. (2014): Imitation vs. innovation in the SME sector. Annals of the Polish Association of Agricultural and Agribusiness Economists, 16 (2): 281-286. 
Takácsné György K., Takács I. (2014): Jellemzö-e a stratégiai gondolkodás az Észak-magyarországi régió kkv-szektorában? COMPETITIO, 13 (1): 88-100.

Vörös J. (2010): Termelés- és szolgáltatásmenedzsment. Akadémiai Kiadó Zrt., Budapest.

VG (2015): A futárcégek és az ételszállítók piacára is be akar törni az Uber. http://www.vg.hu/vallalatok/a-futarcegek-esaz-etelszallitok-piacara-is-be-akar-torni-az-uber449153. (2017.05.02.)

Watts, D. J., Strogatz, S. H. (1998): Collective dynamics of "small-world" networks. In: Nature (393): $440-442$.

Zeng, V. (2015): China Online Retail Forecast, 2014 to 2019. Embrace The Mobile Sales Momentum In China, https://www.forrester.com/report/China+Online+Retail+Forecast+2014+To+2019//E-RES118544. (2015.02.04.) 